\title{
PSYCHOLOGY
}

\section{Aron I.S. \\ The social situation of development of a modern teenager}

\begin{abstract}
The research subject is the detection of the typical age, socio-cultural and individual characteristics of the social situation of development of a modern teenager, on the basis of conceptual regulations of the cultural and historical psychology on the dynamics of a child's mental development. The methodological and practical value of Vygotsky's concept of "social situation of development» is substantiated. On the basis of the analysis of researches by domestic psychologists, directed on the identification of the substantial structure of the social situation of development, the author designates objective and subjective components of the social situation of development. There with, the special role of a subjective component of the social situation of the development defining the personality activity degree concerning the environment influences is accented. The results of the theoretical analysis of a social context, and also of subjective aspects of the social situation of development of modern teenagers, are presented. It is noted that the main age-typical characteristics of the social situation of development of a teenager are aspirations to join the outside world of adults and agemates, and behaviour orientation to norms and values of this world. The socio-cultural characteristics of the social situation of development of a modern teenager are caused by the influence of numerous factors, mainly those of negative content. Individual factors of the development of teenagers also quite often have negative psychological content. That is confirmed by the author, from examples of the content analysis of the social situation of development of teenagers without parental support, teenagers with deviant behaviour and teenagers with endowments signs. The conclusion of the need for the optimization of the social situation of development of a modern teenager is drawn.

Keywords: cultural and historical psychology, social situation of development, development source, teenager, age-typical characteristics, socio-cultural changes, teenagers of a "risk group", orphan teenagers, deviant teenagers, endowed teenagers.
\end{abstract}

Concept of the "social situation of development" as the basis of the psychological analysis of age development dynamics

The concept of the "social situation of development", entered by the outstanding domestic psychologist L.S. Vygotsky, is the basic concept of the age psychology studying age dynamics, regularities and driving forces of the development of mental functions, and of personality throughout the entire course of life of a person. The importance of this concept is defined, on the one hand, by its methodological value, since the concept of the "social situation of development" resists the understanding of the environment as the factor defining the development of the personality mechanically, which representatives of a number of the psychological directions adhere to. The social situation of development, according to L.S. Vygotsky, is not a factor, but the source of development representing absolutely special combinations of internal development processes and external conditions is typical for each age period ${ }^{1}$.

The concept of the social situation of development also possesses great practical value for the carrying out of concrete and empirical researches, not only in age and the pedagogical aspect, but also in other psychology branches. The social situation of development "determines wholly and completely the forms and the path along which the child will acquire ever newer personality characteristics, drawing them from the social reality as well as from the basic source of development, the path along which the social be-

1 Vygotsky L.S., 1984. Works in 6 volumes. Moscow: Pedagogics. V.4. Children's Psychology, 432p. 


\section{Aron I.S.}

comes the individual"2. Therefore the studying of the content of the social situation of development of a child allows us to define the directions of optimization of his/her mental and personal development.

As the analysis of researches of the substantial structure of the social situation of development showed, all authors specify objective and subjective components of the social situation of development.

In Vygotsky's concept, the social situation of development represents a ratio of the external and internal conditions defining the age and individual characteristics of a child. In the opinion of L.I. Bozhovich, the social situation of development is "a certain place in the system of the public relations available to a child" (an objective component of the social situation of development) and "an internal position of a child" (a subjective component of the social situation of development) ${ }^{3}$.

According to Feldstein's concept, the social situation of development at a concrete age makes a system of the relations between a child and society (the position "Me in society" and the position "Me and society") 4 .

The founders of anthropological psychology (Slobodchikov and Isaev) consider the social situation of the development of a child as a unity of his/her joint activity and cooperation with an adult, acting as a carrier of the symbolization of the world and its spiritual meanings, defining the program of participation of a child in newsworthiness 5 .

O.A. Karabanova includes in the dynamic structure of the social situation of development "an objective position of a child in the system of social (conventional and interpersonal) relations: reflection, acceptance and absorption of a social position in the form of an orienting image by a child; hierarchy of the social contexts of communication and interaction of a child with the social environment defining the system of social expectations" 6 .

\footnotetext{
2 Ib. P.258.

3 Bozhovich, L.I., 2001. Problems of Personality Formation: Selectas. Moscow: MPSU, Voronezh: NPO “MODEK”, 352p. P.189.

4 Feldstein, D.I., 1999. Psychology of growing up: the structural and substantive characteristics of the personality development process. Moscow: MPSI; Flinta, 672p.

5 Slobodchikov, V.I., Isaev, Ye.I., 1995. Fundamentals of psychological anthropology. Human psychology: Introduction to Psychology subjectivity. Moscow: Shkola Press, 384p.

6 Karabanova, O.A., 2002. Social Situation of Child's Development: structure, dynamics, correction principles: Dissertation for the degree of Psy.D. Moscow: Lomonosov Moscow State University, 379p. Pp.62-63.
}

In highlighting objective and subjective components of the social situation of development, researchers designate a priority role of a subjective component, which defines the degree of personality activity concerning environmental influences.

Based on the works of leading domestic psychologists, we designated a substantial structure of the social situation of development of a professionally selfdefined personality as a system of objective (social context) and subjective (psychological readiness for professional self-determination) components. The psychological readiness for professional self-determination (cognitive, activity, motivational, personal) determines its success in many respects ${ }^{7}$.

\section{Characteristics of the social situation of development of a modern teenager}

Age-typical characteristics of the social situation of development of a teenager at stable and crisis ages are analysed in detail in the works of the classics of domestic psychology - Vygotsky, L.S. ${ }^{8}$, Bozhovich, L.I. ${ }^{9}$, Elkonin, D.B. ${ }^{10}$, Feldstein, D.I. ${ }^{11}$ and others.

Thus, the special - and peculiar to this age - social situation of development determining the direction, content and nature of a child's development in the normative space of childhood is formed in adolescence. The originality of the social situation of development of a teenager consists in that the outside world of adults and age-mates becomes the centre of his physical and mental development, in which the teenager starts taking a new place, carrying out new functions in comparison with the younger school student ${ }^{12}$.

The important changes of the social situation of development of a teenager are determined in many respects by the role that the group of age-mates plays for a child

\footnotetext{
Aron, I.S., 2014. Professional self-determination in a special social situation of development. Psychology and Psychotechnics, 3: 320 - 328. DOI: 10.7256/2070-8955.2014.3.10425.

8 Vygotsky L.S., 1984. Works in 6 volumes. Moscow: Pedagogics. V.4. Children's Psychology, 432p.

9 Bozhovich L.I., 2001. Problems of Personality Formation: Selectas. Moscow: MPSU, Voronezh: NPO “MODEK”, 352p.

10 Elkonin, D.B., 1995. Mental development in childhood. Moscow: Publishing house "Institute of practical psychology", 416p.

11 Feldstein, D.I., 1999. Psychology of growing up: the structural and substantive characteristics of the personality development process. Moscow: MPSI; Flinta, 672p.

12 Gamezo, V.M., Petrova, Ye.A., Orlova, Ye.M., 2009. Age and pedagogical psychology: Work book. Moscow: Russian pedagogical society, 512p.
} 


\section{Psychology}

at this age. The participation in the group of age-mates is a special way of inclusion of a teenager in life, in socially useful activities, a way of expansion of the sphere of social communication of a teenager, the assimilation of social values and the formation of moral qualities.

The main tendencies of personality development of a teenager consist in changes of motives and aspirations, relations to society as a whole, to definite social groups and to himself. The need for recognition of his importance, and independence in the world of adults, becomes the prevailing requirement. The ability of selfunderstanding and of awareness of his personal qualities develops, and the social activity, aspiration to selfupdating and self-realization increases ${ }^{13}$.

Along with age-typical characteristics of the social situation of development of adolescent children, it is possible to reveal the characteristics of the social situation of development of teenagers caused by the influence of various objective and subjective factors, both of positive and negative psychological content.

Because teenagers are the most dynamic sector of society that is extremely sensitive to its changes, researches in which the features of the social situation of development of a modern teenager created under the influence of socio-cultural changes in society are considered to have special interest. The results of such researches are reflected in the works of Feldstein, D.I. ${ }^{14}$, Kondrashkin, A.V. ${ }^{15}$, Khlomov, K.D. ${ }^{16}$ and others.

Feldstein, analyzing changes of the socio-cultural environment, designates the factors which have a negative impact on the social situation and development of a modern child. The author refers to such factors as the following: the instability of economic, social and political situations; the development of the market relations alienating the child from cultural traditions of society; an unequal access to educational resources in big and small cities; the growth of tendencies to restrict child

13 Feldstein, D.I., 1999. Psychology of growing up: the structural and substantive characteristics of the personality development process. Moscow: MPSI; Flinta, 672p.

14 Feldstein, D.I., 2011. A Changing Child in a Changing World: Psychological and Educational Problems of the New School. Psychology in Russia: State of the Art, 4: 383-396.

15 Kondrashkin, A.V., 2013. Motivational-Need Sphere of the Teenagers in Various Social Situations of Development: Synopsis of Dissertation for the degree of Psy.D. Moscow: Moscow City Psychological-Pedagogical University, 24p.

16 Kondrashkin, A.V., Khlomov, K.D., 2012. Deviant Behavior in Adolescents and the Internet: Change in the Social Situation. Psychology. HSE Journal, 3:102-113.

Nikolaeva, V.V., 1987. The influence of chronic disease on the psyche. Moscow: Publishing house of Lomonosov MSU, 168p. autonomy by parents and a decrease in the motivation of parents to communicate with children.

Under the influence of these and other factors there are qualitative mental, physiological and personal changes to a modern child. Thus, in recent years the inquisitiveness and creativity of children has decreased; there are negative dynamics of the cultural and social values of teenagers; tendencies to individualism have grown, there has been a decrease in the social competence of teenagers, and tendencies to loneliness have come to light. A special alert is caused by the negative influence of the mass media on the development of modern teenagers, and the excessive enthusiasm of children for television, which results in the inability to concentrate on any activity, absent-mindedness, lack of interest and hyperactivity ${ }^{17}$.

Serious changes in the social situation of development of modern teenagers under the influence of mass media and, firstly, by the Internet, are testified to in the results of researches of A.V. Kondrashkin and K.D. Khlo$\operatorname{mov}^{18}$. The authors consider the following to be major factors of change of the social situation of development of modern teenagers: moving of the communication environment of teenagers to the Internet, the use of various gadgets for communication which accelerate and facilitate communication, making it more available, therewith - mediated and superficial. At the same time the social situation of development of modern teenagers is damaged in connection with the change of the role of parents, who in developed social and economic conditions pay more attention to career interests than to communication with a child. That promotes the change of the system of child-parental relations.

A.V. Kondrashkin determines the modern social situation of development of teenagers as a situation of the hidden social and psychological dis-adaptation, which, unlike an obvious situation of the social and psychological adaptation shown in various forms of deviant behaviour, is shown in social isolation, dispassionateness from interpersonal interaction, astenisation, emotional impoverishment, and depressive patterns of behaviour of teenagers ${ }^{19}$.

17 Feldstein, D.I., 2011. A Changing Child in a Changing World: Psychological and Educational Problems of the New School. Psychology in Russia: State of the Art, 4: 383-396.

18 Kondrashkin, A.V., Khlomov, K.D., 2012. Deviant Behavior in Adolescents and the Internet: Change in the Social Situation. Psychology. HSE Journal, 3:102-113.

Nikolaeva, V.V., 1987. The influence of chronic disease on the psyche. Moscow: Publishing house of Lomonosov MSU, 168p.

19 Kondrashkin, A.V., 2013. Motivational-Need Sphere of the Teenagers in Various Social Situations of Development: Synopsis 


\section{Aron I.S.}

From what has just been said above it is possible to draw a conclusion that the content of the social situation of development of a modern teenager is determined by the features of a combination of age-typical characteristics of the social situation of development of a teenager and characteristics caused by sociocultural transformations in modern society, which change the system of relations of a teenager with the social environment surrounding him/her.

Therewith, today, in modern society, the demand for an individual, person-centered approach to the child and his/her development becomes actual. The special importance is gained by tendencies of individualization and subjectivization of the social situation of development, which were determined by L.S. Vygotsky and noted by other researchers of the social situation of development - Nikolaeva, V.V. ${ }^{20}$, Karabanova, O.A. ${ }^{21}$, Slobodchikov, V.I., Isaev, Ye.I. ${ }^{22}$ and others.

In a context of individualization of the social situation of development, V.V. Nikolaeva offered the concept of the "special social situation of development" when studying the influence of a chronic disease on the mentality of a person. As Nikolaeva notes, the "mental activity of a person suffering from diseases changes not because some special mental mechanisms start operating but because the same mechanisms operate in special conditions caused and changed by disease" 23 .

Any chronic disease creates a special, objective social situation of development of the person's mentality, putting the person in psychologically special vital circumstances. The main components of a special social situation of development in the conditions of disease are: the psychological consequences of the influence of biological harm, pre-morbid features of mentality, the main social consequences of disease

of Dissertation for the degree of Psy.D. Moscow: Moscow City Psychological-Pedagogical University, 24p.

20 Nikolaeva, V.V., 1987. The influence of chronic disease on the psyche. Moscow: Publishing house of Lomonosov MSU, 168p.

${ }^{21}$ Karabanova, O.A., 2010. Social Situation of Child's Development - the Key Concept in Modern Developmental Psychology. Psychology in Russia: State of the Art, 3: 130-153.

Prikhozhan, A.M., 1990. Children without family. Moscow: Pedagogics, 158p.

22 Slobodchikov, V.I., Isaev, Ye.I., 1995. Fundamentals of psychological anthropology. Human psychology: Introduction to Psychology subjectivity. Moscow: Shkola Press, 384p.

23 Nikolaeva, V.V., 1987. The influence of chronic disease on the psyche. Moscow: Publishing house of Lomonosov MSU, 168p. P.123. and a change of the internal position of the patient to all the sets of circumstances ${ }^{24}$.

In the modern aggravated socio-cultural and economic conditions of society's development, the growth of the number of teenagers with an increased risk of development of maladaptive forms of behaviour is observed. In this connection it is scientifically and practically interesting to research the content of the social situation of development of teenagers of "risk groups" - teenagers without parental support, teenagers with deviant behaviour, and teenagers with endowments, amongst others.

As researches show, the majority of components of the social situation of development of teenagers of a "risk group" have negative psychological contents. Thus, the social situation of development of teenagers without parental support is characterized by: a social, sensitive and behavioural deprivation; the rigid regulation of all the actions of a child; inadequate organization of vital space; a group approach to children and a lack of individual contacts with adults; emotional simplicity, poverty and monotony of contacts ${ }^{25}$.

The social situation of development of teenagers with deviant behaviour is determined by the following content of the social context of development: the negative attitude of society as a whole to a deviant teenager; the negative attitude of teachers, an aspiration to apply authoritative methods of education; the often low social status of a family, the humiliation of the child's personality; in socially safe families, parents are occupied with the solution of the problems, they don't notice the child and behave towards him/her indifferently; the rejection of a teenager by age-mates ${ }^{26}$.

The negative aspects of a social context are also noted in the social situation of development of teenagers with endowment signs. They include: the ambiguous inconsistent relations with teachers, especially to children with social and creative endowments; difficulties in communication with age-mates; quite often sneers, or rejection by age-mates; family de-centricity, excessive concentration on the child ${ }^{27}$.

24 Ib.

25 Prikhozhan, A.M., 1990. Children without family. Moscow: Pedagogics, 158p.; Furmanov, I.A. 2004. Psychology of a deprived child. Moscow: VLADOS, 319p.

26 Kondrashkin, A.V., Khlomov, K.D., 2012. Deviant Behavior in Adolescents and the Internet: Change in the Social Situation. Psychology. HSE Journal, 3:102-113.; Zmanovskaya, Ye.V., 2003. Deviantology: Psychology of deviant behavior. Moscow: Academy, 288p.

27 Savenkov, A.I., 2010. Psychology of children's gift. Moscow: Genesis, 440p. 


\section{Psychology}

The knowledge of specifics of the social situation of development of teenagers is a basis of the psychological content of their mental and personal development, considering age-typical and individual characteristics of the development of children in the conditions of sociocultural changes in society.

\section{References:}

1. Vygotsky L.S., 1984. Works in 6 volumes. Moscow: Pedagogics. V.4. Children's Psychology, 432p

2. Д.Л. Кущенко. Становление правосознания в подростковом и юношеском возрасте // Психология и Психотехника. - 2012. - № 3. - С. 104-107.

3. А.А. Дзицоев. Нравственно-половое воспитание детей и подростков в семье и школе // Психология и Психотехника. - 2010. - № 8. - С. 104-107.

4. А.С. Поляков. Факторы успешной деятельности учителя при работе с учениками старших классов // Психология и Психотехника. - 2012. - № 3. - С. 104-107.

5. С.А. Шемшурина. Формирование краеведческой компетенции подростков в дополнительном образовании. // Психология и Психотехника. - 2011. - № 1. - С. 104-107

6. Попова А.В., Тарасова С.M. Student's social adaptation in modern cross-cultural conditions // NB: Психология и психотехника. - 2013. - 5. - С. 46 - 60. DOI: 10.7256/2306-0425.2013.5.9461. URL: http:// www.e-notabene.ru/psp/article_9461.html

7. Уддин M.. Personal and motivational aspects of students studying in traditional face-to-face system and distance education system // Психология и Психотехника. - 2014. - 2. - С. 192 - 200. DOI: 10.7256/20708955.2014.2.10932.

\section{References (transliterated):}

1. Vygotsky L.S., 1984. Works in 6 volumes. Moscow: Pedagogics. V.4. Children’s Psychology, 432p

2. D.L. Kushchenko. Stanovlenie pravosoznaniya v podrostkovom i yunosheskom vozraste // Psikhologiya i Psikhotekhnika. - 2012. - № 3. - S. 104-107.

3. A.A. Dzitsoev. Nravstvenno-polovoe vospitanie detei i podrostkov v sem'e i shkole // Psikhologiya i Psikhotekhnika. - 2010. - № 8. - S. 104-107.

4. A.S. Polyakov. Faktory uspeshnoi deyatel'nosti uchitelya pri rabote s uchenikami starshikh klassov // Psikhologiya i Psikhotekhnika. - 2012. - № 3. - S. 104-107.

5. S.A. Shemshurina. Formirovanie kraevedcheskoi kompetentsii podrostkov v dopolnitel'nom obrazovanii. // Psikhologiya i Psikhotekhnika. - 2011. - № 1. - S. 104-107.

6. Popova A.V., Tarasova S.M. Student's social adaptation in modern cross-cultural conditions // NB: Psikhologiya i psikhotekhnika. - 2013. - 5. - C. 46-60. DOI: 10.7256/2306-0425.2013.5.9461. URL: http://www.enotabene.ru/psp/article_9461.html

7. Uddin M.. Personal and motivational aspects of students studying in traditional face-to-face system and distance education system // Psikhologiya i Psikhotekhnika. - 2014. - 2. - C. 192-200. DOI: 10.7256/20708955.2014.2.10932. 